\title{
Jigsaw Cooperative Learning Model on Spectroscopy Subject
}

\author{
Yuni Kartika*, M. Lutfi Firdaus, Eko Swistoro \\ Graduate School of Science Education, University Bengkulu, Indonesia \\ *Email: k.yuni13@yahoo.co.id
}

DOI: https://doi.org/10.33369/bjset.v1i1.11175

\begin{abstract}
The aim of this study was to describe the differences in students' learning outcomes, between those who used the jigsaw learning model and who studied conventionally in analytical chemistry learning. This research used quasi-experimental method with a non-equivalent design and control grup design. The research was conducted at Chemistry Study Program in the fifth semester. In the non-equivalent control group design, the sample was not chosen randomly but by purposive sampling technique. The research implicated two classes, i.e. class $\mathrm{A}$ as the experimental-class and class B as the control-class. Both classes were given pretest to find out the student's initial ability before being given a lesson and also a posttest to find out the student's final ability. This research was conducted in three meetings in accordance with the material to be delivered. In experimental-class, the researchers used jigsaw learning model. In this kind of learning model, there were some stages in the organization where the students could discuss by expressing thoughts, exchanging knowledge, understanding abilities and correcting each other among friends in the group. The average value of the students' final learning outcomes in experimental class showed a value of 70.5 and 60.0 in the control class with a value of sig. (2tailed $)=0.000<$ sig. $\alpha=0.05$. Therefore, it can be concluded that there were significant differences in the student's ability of learning outcomes used the jigsaw learning model and those who used conventional learning.
\end{abstract}

Keywords: Jigsaw learning model, student learning outcomes, UV- vis spectrophotometry, analytical chemistry.

\section{INTRODUCTION}

The development and progress of a nation is influenced by the quality of education. Education is used as a mean that can be utilized to measure the quality of a nation. Besides, through education there will be people who are pious, knowledgeable, independent and responsible. In the process of education, teaching and learning are two concepts that cannot be separated. Learning shows what a person or learner must do as a subject who receiving a lesson (students), while teaching shows what the teacher have to do. Based on the observations found in the field during practicum activities, students only carry out activities according to procedures that have been made by previous lecturers and lack of broader insights regarding various applications of analytical chemistry concepts (Sanjaya, 2006). Analytical chemistry is a chemical analysis that can be in the form of a qualitative analysis aimed at determining and identifying a substance while quantitative analysis aimed to determine the amount of a substance that can use spectroscopy method (Firdaus, 2017). 
Many students feel confused and difficult to explore the material delivered by the lecturer. Consequently, the students tend to be lazy to find information from outside or from various sources of reference. This affects the lack of student understanding to the material being taught, so that the impact is less good on student learning outcomes. Therefore, the selection of student learning models in the learning process is required, namely the Jigsaw learning model. Jigsaw learning model is a type of cooperative learning that encourages students to be more active and help each other in mastering subject matter to achieve maximum achievement (Monalisa, 2015).

With the activities undertaken by students, cooperative learning becomes relevant for use in increasing student collaboration in groups. In this kind of learning model, there are some stages in the implementation where students can discuss by expressing their thoughts, exchanging knowledge, understanding abilities and correcting each other among friends in the group. Jigsaw learning model gives students the opportunity to learn the subject through discussion. The discussion is divided into two section. The first discussion is done with expert groups to solve existing problems and the second section is home group discussion to account for the results of group discussions (Sulastri, 2009).

In the learning process, the Jigsaw learning model will be developed as a Student Worksheet from the analysis of a mixture of coffee and palm cooking oil. In this study, Student Worksheets were used by Chemistry Education students at Bengkulu University. Student Worksheet is a guideline for the students in understanding the skills of the processes and concepts of the material to be studied (Isnangsih, 2013). An innovation that can be done to overcome this problem is through media development in the form of local creative based Student Worksheets that can arouse student interest if it is arranged neatly, systematically, easily understood so that it is easy to attract students' attention and increase learning motivation and curiosity (Dimyati, 2009). One of the uses of Jigsaw learning model from the spectrophotometer application is to find out the mixture of coffee and palm cooking oil that is a product which sold in the market. In this case, the researchers used coffee and palm cooking oil as the solution that the impurity was investigated.

\section{RESEARCH METHODS}

This research was conducted from October 1 to November 30, 2019 in the Chemical Education Study Program. The method in this study was a quasi-experimental method with a research design that used was non equivalent control group design. The study design is shown in Table 1.

Table 1. Nonequivalent Control Group Design

\begin{tabular}{lccc}
\hline \multicolumn{1}{c}{ Class } & Pretest & Treatment & Postest \\
\hline Experiment & $\mathrm{O}_{1}$ & $\mathrm{X}$ & $\mathrm{O}_{2}$ \\
Control & $\mathrm{O}_{3}$ & $\mathrm{Y}$ & $\mathrm{O}_{4}$ \\
\hline
\end{tabular}

The study population was all chemistry students in semester $\mathrm{V}$, totaling 2 classes. The sample in the study was selected by purposive sampling technique. There are two classes as the sample in this study, namely class A with 24 people and class B with 24 people. The experimental class was given treatment in the form of a jigsaw learning model while the control class was given conventional learning. The techniques of research data collection were obtained from tests given to the samples in accordance with the material being taught. Furthermore, the test was carried out twice, namely before (Pretest) and after (Postest) treatment (Sudjana, 2011). 


\section{Pretest}

Pretest (initial test) were carried out with the aim to find out the student's initial understanding of the concept of Analytical chemistry before the lesson material was given to students. After the pretest (initial test) was given for the experimental class and the control class, then the regular test is done to see whether the data obtained is normal or not, if in the pretest the normal data is obtained, then the t-test will be performed.

Posttest

Posttest (final test) was conducted with the aim of knowing the final knowledge of students about UV-vis spectrophotometry that had been taught. The final test was made as the same as the pretest so that it can be seen and known whether the final test results were better, the same or even worse than the initial test. If the results of the final test are better than the initial test, it can be concluded that the application of the jigsaw learning model had been running and succeeded well. Conversely, if the results of the final test are lower than the initial test, it could be concluded that the implementation of the jigsaw learning model did not work well.

\section{RESULTS AND DISCUSSION}

\section{Initial Ability}

Pretest was conducted to determine the students' initial ability to UV-vis spectrophotometric material. Based on the calculation results, the recapitulation of the results of the pretest can be seen in Table 2.

Table 2. Recapitulation of Pretest Results Data

\begin{tabular}{ccc}
\hline Categories & Experiment Class & Control Class \\
\hline The average value & 46.2 & 44.7 \\
Standard deviation & 15.9 & 15.6 \\
The highest score & 54 & 52 \\
The lowest score & 36 & 36 \\
\hline
\end{tabular}

Based on table 2 it can be seen that the average value of the pretest of the experimental class is 46.2 and that of the control class is 44.7 . The pretest data above shows descriptively that the critical thinking ability between the experimental class and the control class there were not such a large difference because UV-vis spectrophotometry material had not been studied yet by the students.

\section{Final Ability}

Post test was conducted to determine the student's final ability on UV-vis spectrophotometry material after getting a different learning treatment. Based on the calculation results, the recapitulation of the post-test results can be seen in Table 3.

Table 3. Recapitulation of Post Test Results Data

\begin{tabular}{ccc}
\hline Categories & Experiment Class & Control Class \\
\hline The average value & 70.5 & 60.0 \\
Standard deviation & 31.9 & 26.7 \\
The highest score & 97 & 80 \\
The lowest score & 42 & 40 \\
\hline
\end{tabular}

Based on Table 3, it can be seen that the average post test score of the experimental class is 70.5 and in the control class is 60.0. The data above shows that descriptively the results of the student's final ability test were different between the experimental class and the control 
class. The comparison of the average value of the pretest and posttest of the experimental class and the control class. The initial ability of the experimental class showed differences that were not much different in the control class before being given learning. Meanwhile, the final ability of the experimental class showed a greater improvement than the control class after being given different treatment in the process of learning.

By looking at the completeness data obtained in both classes, the experimental class has a greater level of completeness than the control class. This shows that the usage of jigsaw model in learning activities makes the students more active in the learning process. The activity caused by students can influence the learning outcomes obtained at each meeting. Regarding learning using the jigsaw model, the students were more active while the learning activities because they thought and found the final results independently, but the hat creates a sense of satisfaction and encourages to make more discoveries to generate a high learning interest.

\section{Hypothesis test}

From the results of normality and homogeneity tests of pretest average data, it can be concluded that the two classes are normally distributed and homogeneous. The parametric $t$ test was performed using SPSS. Based on the testing criteria, if the significant value $<\alpha 0.05$ then Ho is rejected and $\mathrm{Ha}$ is accepted. In the $\mathrm{t}$ test calculation using the SPSS 25 application and the hypothesis used:

$\mathrm{Ho}=$ There is no difference between the mean score of the experimental class and the mean score of the control class

$\mathrm{Ha}=$ There is a difference between the average score of the experimental class and the average score of the control class

Based on the analysis, the calculation of the pretest and posttest test of both the experimental and control classes can be seen in Table 4 .

Table 4. Pretest and Posttest Test Results

\begin{tabular}{cccc}
\hline Test & Sig. $\boldsymbol{\alpha}$ & Sig(2-Tailed) & Conclusion \\
\hline Pretest & 0.05 & 0.567 & Not significantly different \\
Posttest & 0.05 & 0.000 & Significantly different \\
\hline
\end{tabular}

Based on the results of the t-test calculations above, the final ability shows that for the pretest value obtained sig. (2-tailed) $=0.567$ is greater than $\alpha=0.05$, it is stated that there is no significant difference in the initial learning outcomes of the experimental class students and control class students, while the posttest score sig. (2-tailed) $=0,000$ smaller than $\alpha=0.05$. This means that Ho was rejected Ha was accepted. Thus, the hypothesis proposed in this study is accepted, so that students' learning outcomes using the jigsaw learning model on LKM UVvis spectrophotometry material is greater than students' learning outcomes taught using conventional learning.

\section{CONCLUSIONS}

Based on the research results and discussion section that previously described, it can be concluded that there is a significant difference between the ability of students' learning outcomes using the jigsaw learning model with the ability of students' learning outcomes using conventional learning on UV-vis spectrophotometry material. The average value of the final learning outcomes of the experimental class students showed a value of 70.5 and a control class of 60.0 with a value of sig. (2-tailed) $=0,000$ that is less than sig. $\alpha=0.05$. This jigsaw learning 
model can be used as a reference in variation of the learning process, and can be one of the references for subsequent research.

\section{REFERENCES}

Dimyati and Mudjiono. (2009). Belajar dan Pembelajaran. Jakarta: Creative Design.

Firdaus, M., Andriana, S., Alwi, W., Swistoro, E., Ruyani, A., \& Sundaryono, A. (2017). Green synthesis of silver nanoparticles using Carica Papaya fruit extract under sunlight irradiation and their colorimetric detection of mercury ions. In Journal of Physics: Conference Series (Vol. 817, No. 1, p. 012029). IOP Publishing.

Isnangsih and Bimo, D.S. (2013). Penerapan Lembar Kegiatan Siswa (LKS) Discovery Berorientasi Keterampilan Proses Sains Untuk Meningkatkan Hasil Belajar IPA. Jurnal Pendidikan IPA Indonesia (JPPI), 2(2), 136-141.

Monalisa, L. A., \& Trapsilasiwi, D. (2015). Penerapan Model Pembelajaran Kooperatif Tipe Jigsaw Pada Pokok Bahasan Keterbagian Bilangan Bulat Untuk Meningkatkan Aktivitas Mahasiswa Semester Vi Tahun Ajaran 2014-2015 Program Studi Pendidikan Matematika Fakultas Keguruan Dan Ilmu Pendidikan Universit. Pancaran Pendidikan, 4(2), 173-180.

Sanjaya, Wima. (2006). Strategi pembelajaran Berorientasi Standar Proses Pendidikan. Bandung: San Grafika.

Sudjana, N. Rivai Ahmad. (2011). Media Pengajaran. Bandung: Sinar Baru Algensindo.

Sulastri, Yeti and Rochintaniawati, Diana. (2009). Pengaruh Penggunaan Pembelajaran Kooperatif Tipe Jigsaw dalam Pembelajaran Biologi Di SMPN 2 Cimalaka. Jurnal Pengajaran MIPA, 13(1), 22. 